\title{
Die Hellenisties-Romeinse wêreld en die ontstaan van apokaliptiek en gnostisisme
}

$\mathrm{M} \mathrm{Nel}^{1}$

(Universiteit van Pretoria)

ABSTRACT

The Hellenistic and Roman world and the origin of the apocalypticism and gnosticism

The world view and culture created by the oikoumene of the HellenisticRoman era (331 BC to early fourth century $A D$ ) was conducive to the rise of several philosphico-religious movements, like Mithraism and other mystery religions; Stoicism, Epicureanism and Middle Platonism; apocalypticism and wisdom literature in Hellenistic Judaism and Gnosticism. These movements have in common that they originated in a world defined by change and insecurity, leading to an attitude of alienation, despair and agony amongst many people. These people looked for a soter, and the philosophico-religious movements offered such soteria, salvation from an alien and evil world and entrance to a new world. Jewish apocalypticism flourished during the period from the third century $B C$ to the first century $A D$, when orthodox rabbi's started purifying Jewish religion from all foreign hellenistic elements like the dualistic views of apocalypticism. When this happened Christianity had already adopted the essence of Jewish apocalypticism. During the second century $A D$ some Christians were disappointed that the parousia had not realised as expected imminently, and from their disappointment grew their involvement in gnostic Christian movements, centered around strong leaders (guru's). Our age is also characterised by change and insecurity, just as the case was during the Hellenistic-Roman age, and the hypothesis of the article concludes with the assertion that the phenomenal growth in the New Age movement and neo-paganism can be explained in the same terms as apocalypticism and gnosticism.

\section{INLEIDING EN HIPOTESE}

Raakvlakke tussen die sosiale oorsprong en wêreldbeeld van apokaliptiek en gnostisisme bestaan. Die raakvlakke bestaan uit die gedeelde wêreld waarbinne albei verskynsels voorkom: die Hellenisties-Romeinse era.

Die hipotese van hierdie artikel wil dit voorhou dat (Joodse) apokaliptiek uit individue se belewenis van hul wêreld, die HellenistiesRomeinse wêreld, gebore is ${ }^{2}$. Derde en tweede eeuse Joodse apokaliptiek,

1 Na doktorale genoot, Departement Ou Testament, Universiteit van Pretoria.

2 Die bespreking van apokaliptiek word vir doeleindes van dié artikel tot Joodse apokaliptiek beperk. Daar bestaan verbande tussen Joodse en ander vorme van apokaliptiek. Die verband tussen byvoorbeeld Zoroastranisme en Joodse apokaliptiek 
wat deurgaans op die rand van die Joodse godsdiens gefunksioneer het, word in $70 \mathrm{nC}$ totaal uitgeskuif as Judaïsme met die nasionale ramp van die val van Jerusalem direk onder die invloed en mag van die rabbi's kom. Die rabbi's verwerp Hellenistiese Judaïsme se filosofiese interpretasie van die Tora asook die apokaliptiese sienings en wysheidsteologie wat daaruit gebore is. Die moontlikheid bestaan dat die rabbi's die skuld vir die onderdrukking van Joodse nasionalisme in $70 \mathrm{nC}$ deur die Romeine voor die deur van die verhellenisering van Judaïsme (veral Aleksandrynse Hellenistiese Judaïsme) kon lê. Teen $70 \mathrm{nC}$ het die Christendom reeds wyd veld gewen. Die Christelike kerk begin as ' $n$ Joodse beweging, maar weldra sluit heidene daarby aan. Ná 70 nC vervolg die Jode die Joodse Christene openlik omdat hulle pasifisties was en nie aan die Joodse Opstand van $68 \mathrm{nC}$ deelgeneem het nie. Die handjievol Christene wat in Palestina oorgebly het, wyk uit na Pella.

Die Christene het die belangrikste temas van Joodse apokaliptiek oorgeneem. In hul apokaliptiese verwagting deel hulle Joodse apokaliptiek se pessimisme oor dié wêreld, en verwag 'n beter een.

Die volgende ontwikkelingsfase, luidens die hipotese, kom na vore as baie Christene teen die tweede eeu teleurgesteld in hul immanente wederkomsverwagting staan. Uit die teleurgestelde verwagting groei onder andere die Gnostiese beweging langs die Christelike kerk. Gnostieke se pessimisme gee aanleiding daartoe dat hulle ook (in meeste gevalle) ' $n$ beter wêreld verwag, maar terselfdertyd aktief dié wêreld afskryf deur materie en die liggaam van die mens as boos en sleg af te maak.

Wat Joodse apokaliptiek van die twee of drie eeue $\mathrm{vC}$ met die Christelike kerk en Gnostiese beweging in gemeen het, is die filosofiese wêreldbeeld, antropologie en teologiese ondertone wat uit die oikoumene van die Hellenisties- Romeinse era ontstaan.

Die artikel sluit af met ' $\mathrm{n}$ verwysing na die postmoderne situasie met die ontstaan van New Age-sektes en neo-paganisme. Dit vertoon ooreenkomste met apokaliptiek sowel as gnostisisme. Die laaste deel van die hipotese beweer dat die hedendaagse situasie veel in gemeen het met die Hellenisties-Romeinse situasie, en vir dié rede tot dieselfde denkfenomene aanleiding gee.

\section{HELLENISTIES-ROMEINSE DENK- EN LEEFWêRELD}

Die Hellenistiese era breek aan in $331 \mathrm{vC}$ as Aleksander van Masedonië die Pers, Darius III, by Gaugamela oorwin en in 'n oomblik sy ryk se grense uitbrei van die Aegeïese See in die ooste tot die Indusrivier in die weste, van die noordelike grense van die Swart See tot Nubië en die

kom na vore wanneer die bronne ondersoek word - vergelyk hiervoor byvoorbeeld Hanson (1975:8-9, 76, 274-275) en Cohn (1993:3-115). 
Sahara in Noord-Afrika. Die era eindig as Oktavianus in $31 \mathrm{vC}$ vir Antonius en Kleopatra by Aktium verslaan. Die Romeinse era strek tot die vierde eeu nC, as Konstantyn in $324 \mathrm{nC}$ die Christelike godsdiens begin aanhang, en veral in $380 \mathrm{nC}$ as Theodosius die Christelike godsdiens as die amptelike staatsgodsdiens proklameer en in $391 \mathrm{nC}$ alle ander aanbiddingsvorme verbied.

Die stelling word dikwels en tereg gemaak dat gevange Griekeland haar oorheerser gevange geneem het. Hiermee word bedoel dat die Hellenistiese kultuur so sterk en lewenskragtig was dat dit die Romeinse kultuur oorskadu en gevorm het ${ }^{3}$. Vir dié rede is dit wenslik om van die Hellenisties-Romeinse era as ' $n$ entiteit te praat.

Die Hellenisties-Romeinse era is gekenmerk deur vervreemding, angs en onveiligheid ${ }^{4}$. Aleksander se oorwinnings verander die geografie van die Griekse wêreld. Skielik kom Ooste en Weste direk in verbintenis met mekaar. Die mense se lewenspatrone verander onherroeplik. Groot groepe Grieke emigreer na die nuwe kolonies onder Griekse oorheersing (Lucas 2002:40). Die Griekse immigrante is die minderheid, maar vorm die heersersklas. Die Griekse kultuur word aan nuwe wêrelde blootgestel en verander in die proses. Die nuwe kultuur staan as die "Hellenistiese" bekend $^{5}$. Die hele bewoonde wêreld word blootgestel aan die nuwe vorm van die Griekse kultuur, sodat die Hellenistiese wêreld 'n oikoumene vorm, 'n wêreldgemeenskap verenig deur 'n koine-taal en kultuur (Grant 1953:XIII; Koester 1982:164-182).

Kontak tussen Griek en nie-Griek lei tot sinkretisme, 'n mengsel van Griekse en oosterse elemente (Martin 1987:6). Veral op die terrein van godsdiens kan dit duidelik gesien word. Sinkretisme is moontlik die belangrikste kenmerk van die Hellenistiese periode (Grant 1953:6; Koester 1982:164).

Die mens beleef nou ' $n$ verskuiwing van nasionalisme na kosmopolitanisme, van die veilige, geïsoleerde stadstaat na die oikoumene, wat Aleksander die Grote se droom vir die wêreld was, en van kollektiwisme na indiwidualisme. Mense word meer mobiel, ou tradisies en waardes word opgehef en afgemaak as outyds en nutteloos, statiese klasse-strukture begin vervaag en verdwyn, sekerhede van die verlede word in die weegskaal van kritiese denke geplaas en die toekoms raak onseker. Teen

3 Die Hellenistiese kultuur se invloed is duidelik tot in die Renaissance-periode.

4 Vir volledige besprekings van dié wêreld, vergelyk Grant (1953); Angus (1967); Dodds (1970); Grant (1982); Koester (1982); Martin (1987); Smith (1990) en Walbank (1993).

5 Die term is die eerste keer in die negentiende eeu nC gebruik om te verwys na die nuwe kultuur wat uit die Griekse gegroei het. Die Hellenistiese kultuur groei uit die klassieke Griekse kultuur, maar vertoon unieke eienskappe. 
die tweede eeu $\mathrm{vC}$ is dié wêreld getraumatiseer deur barbare-invalle wat talle lewens geëis het en groot vernietiging gebring het, bloedige burgeroorloë, plae wat herhaaldelik oor streke swiep, hongersnode en ander natuurrampe en ekonomiese resessies. En omdat die wêreld internasionaal geword het, neem almal kennis van wat in een streek of area gebeur.

Hiermee saam het vertroue in die tradisionele kultusse en stamgode in die slag gebly. Dié vertroue was die basis en grondslag vir die politieke, sosiale en intellektuele lewe. Die publiek het nie meer hul vertroue op die antieke gode geplaas nie. Die gode was duidelik nie in staat om mense te help om die moeilikhede van die daaglikse lewe te trotseer nie. Heersergodsdienste het nou in die plek van stadstaatgode gekom, maar dié godsdienste was slegs burgerlik van aard en het as politieke verskynsel nie aan die behoeftes van die individu voldoen nie.

Die onveiligheid wat die daaglikse bestaan gekenmerk het, het aanleiding gegee tot 'n nuwe belangstelling in die individu se soteria, ' $\mathrm{n}$ heil wat bestaan het uit uitkoms van daaglikse mislukking en swaarkry. Mense het gewag vir ' $n$ boodskap van hoop wat op verlossing sou dui. Hulle het 'n persoonlike redder/saligmaker verwag, iemand wat hulle kon red en beskerm in hierdie lewe en in die lewe ná die dood. Die boodskap van hoop is uitgedra, deur die misteriegodsdienste sowel as filosofie. Die Hellenisties-Romeinse era was ' $n$ godsdienstige tydperk. Ou en nuwe kultusse (Demeter, Dionisius, Isis en Sibele of Magna Mater) sowel as godsdienstige filosofieë (Stoïsisme, Epikureanisme en middelPlatonisme) bied almal aan om die probleme van die mensdom op te los. Hulle wil aan die mens ' $n$ weg tot saligheid bied deur kennis en begrip van die oorsprong en aard van die heelal en die mens.

In die vierde eeu $\mathrm{vC}$ leer Plato nie dat die gode nie bestaan nie. Trouens, hy beklemtoon vir politieke redes dat dit belangrik is om die gode te dien. Wat hy wel doen, is om die gode as filosofiese abstraksies voor te stel, en nie as antropomorfiese wesens nie.

Nou verwant aan skeptisisme oor die gode is die ontwikkeling van ' $\mathrm{n}$ nuwe, uitgebreide wêreldbeeld wat ook ruimte laat vir nadenke oor die mens en sy bestemming. Die klassieke kosmos bestaan uit ' $n$ hiërargie met drie verdiepings. Die heel boonste verdieping is die geboë lug waarin die sterre verstrooi is en die gode woon. Die Grieke glo dat die gode die gebeure op aarde en bestemming van die mens bepaal. Onder die lug is die aarde, 'n plat skyf wat deur water omring is. Onder die aarde is die onderwêreld waar die dooies nog as dowwe skaduwees leef.

Teen die vierde eeu $\mathrm{vC}$ het astronomie groot spronge gemaak en filosofie in staat gestel om 'n nuwe wêreldbeeld te ontwerp. Nou word die wêreld gesien as ' $n$ ewige, volmaakte sfeer wat uit ' $n$ stelsel van 
konsentriese bewegende sfere bestaan. Heel in die middel is die aarde, die eerste en oudste van die sfere. Rondom die aarde se sfeer wentel die sewe planete. Die kosmos bestaan uit twee ryke - 'n bo-maanse en ondermaanse ryk. Die maan is die grens tussen die twee ryke. Bokant die maan is die sfeer van hemelse liggame, sterre en planete wat in ewige harmonie beweeg. Die ondermaanse wêreld is die wêreld van materie die plek van korrupsie, verganklikheid, bedrog en selfsug, en die $\operatorname{dood}^{6}$. Die mens was pessimisties oor sy wêreld ${ }^{7}$.

Beide die materiële en geestelike wêreld was die skeppingsproduk van 'n demiurg, of skeppergod. Die mens is ' $n$ vreemdeling, ' $n$ swerwer in die materiële wêreld. Die mens se ware wese, sy siel, is onsterflik. Die siel behoort aan die transendente geestelike wêreld. Die mens se doel op aarde is om homself van die materiële wêreld te reinig en terug te keer na gemeenskap met die goddelike deur sy rede uit te bou en ' $n$ deugdelike lewe te lei in ooreenstemming met die rede. Die mens se rede is ' $n$ afskaduwing van goddelike rede, of Logos. Die beloning en straf wat op die mens in die lewe hierna wag, word bepaal deur die mate wat hy in ooreenstemming met die rede op aarde geleef het ${ }^{8}$.

Die nuwe kosmologie met sy siening van die mens, asook die nuwe Hellenistiese kosmopolitanisme, verswak geloof en vertroue in tradisionele gode. Die gode ontvang nog seremoniële aanbidding as die mens oortuig is dat die tradisionele bewaar moet word. Maar die gewone mens se lewe word nie geraak deur tempeloffers en -rituele nie. Hy plaas nie meer sy hoop of vertroue in die antieke gode nie, want die gode kan nie hulp bied in die wisselvalligheid van die daaglikse lewe nie.

Ook die heerserskultus wat in die plek van die tradisionele godsdiens kom, kan nie die gewone mens opgewonde maak nie. Die heerser het homself as soter verklaar, die een wat vrede en stabiliteit vir sy onderdane belowe. Maar die kultus vervul nie die behoeftes van die mens op straat nie. Mense soek 'n persoonlike redder, iemand wat hulle kan sterk maak en ondersteun in ' $n$ veranderende wêreld en wat aan hulle onsterflikheid en geluk ná die dood kan skenk.

Die hipotese van dié artikel is dat dit vanuit dié begeerte is dat die misteriekultusse, rasionele filosofie, apopkaliptiek en gnostisisme gebore

\footnotetext{
6 Vir ' $n$ volledige beskrywing van die wêreldbeeld, sien Plato (ca. 427-348) se Wette en Timaeus, asook Aristoteles (ca. 384-322) se Metereologie en Metafisika. Vergelyk ook Nilsson (1946:20-27).

7 Daar moet ook in gedagte gehou word dat die lewensverwagting van die mens uit dié era baie laag was. Mans het gemiddeld die laat twintigs of vroeë dertigs gehaal, terwyl vroue dikwels in hul vroeë twintigs gesterf het vanweë die gevare verbonde aan kindergeboortes.

8 Plato lê veral in sy Phaedrus en Phaedo sterk klem op die retribusie-beginsel.
} 
word. Wat die onderskeie verskynsels in gemeen het, is die wêreldbeeld wat dit deel, en die behoeftes wat uit dié wêreldbeeld gebore is ${ }^{9}$.

\section{ONTSTAAN VAN APOKALIPTIEK}

Die Jode, veral dié wat in die Diaspora was, is nie onaangeraak gelaat deur die ontstaan van die oikoumene van die Hellenisties-Romeinse wêreld nie. Kosmopolitanisme, en die ontstaan van 'n nuwe wêreldbeeld, het ook hul nadenke gestimuleer en beïnvloed. Die hellenisasie van Diaspora Judaïsme kan as Hellenistiese Judaïsme beskryf word.

Inligting oor die Joodse Diaspora is skaars en gefragmenteerd, en dikwels gebaseer op bronne wat nie akkurate historiese bronne is nie. Wat wel afgelei kan word, is dat die Diasporasituasie in Egipte, Klein-Asië, Sirië, Griekeland en (later) Rome naastenby dieselfde was. Daar was nie vervolging van of vyandigheid teen Jode tot die tyd van Romeinse oorheersing in die laaste helfte van die eerste eeu nC nie. Die Jode het nie burgerskap ontvang nie, alhoewel individuele Jode soms deur spesiale toestemming van die regering die voorreg ontvang het.

Wat belangrik is, is dat die Joodse Diaspora, veral in Aleksandrië, gou die taal en denke van Hellenisme geassimileer het ${ }^{10}$. Reeds in die vroeë derde eeu vC het die Aleksandrynse Jode Grieks as hul huistaal aanvaar, volgens papiri wat ontdek is (Feldman 1993:51-52). En hulle het begin om hul religieuse idees aan te pas by die intellektuele klimaat wat deur die heersende kultuur geskep is. Hellenistiese Jode bid, sing, praat en skryf in Grieks ${ }^{11}$. Hellenistiese Jode produseer Griekse literatuur beïnvloed deur Griekse denke (Feldman 1993:52). Die Septuaginta (die Griekse vertaling van die destydse Ou Testament) is moontlik die belangrikste faktor in die groei van Judaïsme tot ' $n$ wêreldgodsdiens.

Enige vertaling is ' $n$ interpretasie, ook die Septuaginta. Die Hebreeuse frases en idees is vertaal in terme van Griekse konsepte, wat dikwels

9 Vir ' $n$ verdere bespreking van die gemene element in misteriegodsdienste, Griekse filosofie, apokaliptiek en gnostisisme, vergelyk Nock (1964:116-124) en Smith (1990:60-81).

${ }^{10}$ Veral Philo Judaeus (of ook Philo Alexandrinus genoem) wat van ca. 20vC-50nC leef, korreleer Bybelse openbaring met Griekse filosofie. In die proses ontwikkel hy ' $\mathrm{n}$ interpretasiemodel, allegorie. Hy interpreteer die Pentateug allegories sodat hy Hebreeuse teologie suksesvol met Griekse filosofie versoen. Allegorie is reeds deur die Griekse eksegete beoefen, vanaf die sesde eeu vC totdat dit deur die Stoïsyne gesistematiseer is.

11 Die Septuaginta is waarskynlik die belangrikste literêre prestasie van Hellenistiese Jode. Die Septuaginta ontstaan gedurende die regering van Ptolemeus II Philadelphus (282-246 vC), en is waarskynlik teen ongeveer $250 \mathrm{vC}$ voltooi. Die Septuaginta speel ' $n$ belangrike rol in die hellenisering van Judaïsme en word ' $n$ belangrike medium om Joodse godsdienstige ervaring aan buitestanders te verduidelik. 
gelade filosofiese terme was. So word Griekse idees in die Hebreeuse wêreld bekend gestel. Die vertalers van die Septuaginta het sover moontlik probeer om die vertaling letterlik te doen, maar talle Hebreeuse woorde en idiome het nie Griekse ekwivalente gehad nie.

Vanuit die Septuaginta begin Jode mettertyd Hellenistiese idees te assimileer in hul teologiese denke en heg hulle 'n nuwe betekenis aan sommige konsepte. Die Skrif word nou gelees vanuit die invloed wat die Hellenistiese wêreld daarop uitoefen.

Deels as gevolg van die invloed van Hellenistiese kulturele en filosofiese invloede ontwikkel daar mettertyd in die Joodse teologiese wêreld apokaliptiese literatuur asook wysheidsliteratuur. Apokaliptiek en wysheid verander fundamenteel Israel se teologiese denke, en oefen ' $n$ (groot) invloed uit op Joodse teologie, tot ten minste die einde van die eerste eeu $\mathrm{nC}^{12}$.

Die oorspronge van apokaliptiek kan nie duidelik bepaal word nie, by gebrek aan duidelike historiese dokumentering van die verskynsel. Die navorser is aangewese op enkele historiese bronne wat bewaar gebly het. Die dualisme van apokaliptiek kan moontlik teruggaan tot Zoroastrianisme, die antieke godsdiens van Persië. Wat wel waar is, is dat die filosofies-godsdienstige klimaat 'n belangrike rol gespeel het in die derde en tweede eeuse (vC) ontstaan (of herlewing) van die apokaliptiek in Judaïsme. Apokaliptiese elemente speel ' $n$ rol in vroeëre Bybelse geskrifte, veral in Esegiël en Deuterojesaja, maar dié geskrifte staan veel nader aan die profetiese geskrifte van die Ou Testament (Hengel 1974:180-181).

Joodse apokaliptiese geskrifte floreer en geniet groot populariteit sowel binne Palestina asook in die Diaspora tussen 200 vC en 90 nC. Dit vervang profetiese literatuur wat tot 'n einde gekom het. Die apokaliptici werk in die profetiese tradisie, veral as dit ook van die element van voorspelling gebruik maak. Maar dit dra ook ' $n$ nuwe element in, wat bestaan uit die wêreldhistoriese, kosmiese beskrywing van die einde van die aarde en die mensdom. Dié element word gebore uit die tydsgees van pessimisme, wat ' $n$ direkte gevolg is van die wêreld- en mensbeeld wat deur Hellenistiese kosmologie ontwikkel is.

Sover afgelei kan word uit oorgelewerde apokaliptiese werke, het apokaliptici in tye van swaarkry en verdrukking geskryf. Die omringende

\footnotetext{
${ }^{12}$ Wat die werklike invloed van apokaliptiek op Joodse teologie was, kan nie bepaal word nie omdat die historiese prosesse nie gedokumenteer is nie. Dat Christus wel in apokaliptiese denke gefunksioneer het, soos duidelik word uit Markus 13 se apokaliptiek, en dat die Dooie See-gemeenskap apokalipties gefunksioneer het, dui wel daarop dat ten minste sekere segmente direk deur apokaliptiek beïnvloed is. Vergelyk Evans \& Flint (1997:74-100) vir verdere bespreking van die onderwerp.
} 
wêreld is negatief beleef, terwyl die onderliggende temas dié van vervreemding, angs en wanhoop is. Dit is in breë trekke die lewensingesteldheid van die Hellenistiese mens.

Die Jode se verdrukking en swaarkry word deur die apokaliptikus teen 'n kosmiese agtergrond geplaas. Die situasie word verplaas van die lokale of nasionale na 'n universele, waar die hele wêreld met bonatuurlike tekens en ingrype tot 'n einde gebring word. Pessimisme oor die bestaande wêreld van materie gaan oor in 'n finale oordeelsdaad van JHWH, as die wêreld vernietig word.

Die navorser gaan nie ' $n$ sistematiese beskrywing van die verskynsel van Joodse apokaliptiek bied nie, deels omdat die bronne skaars is, en deels omdat bestaande bronne divers is (Russell 1964: hoofstuk VIII). Apokaliptiese literatuur is nie homogeen nie, maar toon duidelike verskille in vorm, klem, aanbieding van die boodskap, en die boodskap self (Nel 2000:278). Davies (1985:66) se waarskuwing is gepas: “'Apocalyptic' and 'apocalypticism' are notoriously slippery words”.

Wat wel gesê kan word, is dat apokaliptiese literatuur voorgee om goddelike openbarings te wees in die vorm van ' $\mathrm{n}$ reeks drome of visioene wat aan ' $n$ bekende antieke Bybelse figuur geopenbaar is, byvoorbeeld Henog, Adam, Esra of Daniël. Die drome of visioene word deur ' $n$ engel geïnterpreteer. In misterieuse taal word goddelike geheime oor die mens se toekoms en bestemming bekend gemaak. Die laaste gebeure wat tot die einde van die aarde lei, word beskryf, en deur verskeie literêre tegnieke word beklemtoon dat dié einde op hande is. Die doel van die beskrywing is deurgaans om die verdruktes en lydendes te troos.

Apokaliptici verdeel die mens se geskiedenis in eras of periodes. Baie van hulle dink in terme van vier sulke periodes ${ }^{13}$. Die geskiedenis word beskryf asof dit die toekoms vanuit die perspektief van die antieke Bybelse figuur is. Die rede hiervoor is dat die toekomsvoorspelling dan baie akkuraat is, wat die leser oortuig om die res van die voorspelling, in terme van sy eie toekoms, te aanvaar.

Die teologiese perspektief wat gebruik word, is dat JHWH in absolute beheer is. Hy besluit wie wanneer regeer, en wat die regeerder doen. En Hy skik die geskiedenis met die oog op die belange van sy uitverkore volk, Israel.

Mitiese beelde wat ryk is aan simboliek word aangewend om ' $\mathrm{n}$ wêreld te skets wat op die verbeelding van die leser/hoorder inspeel. Persone, nasies en historiese gebeure word beskryf, en deur die engel

13 Alhoewel daar ook beskrywing van sewe, tien en twaalf periodes te boek gestel is. 
geïnterpreteer. Dié interpretasie self is dikwels oop vir meer as een verduideliking.

Apokaliptici dink pessimisties oor die wêreld, en vanuit ' $n$ duidelike dualisme. Die wêreld is boos en ongeneeslik siek, in teenstelling met die Ou Testamentiese profetiese tradisie wat geglo het dat die wêreld onder God se beheer is en vir dié rede herstelbaar. God beheer die wêreldgeskiedenis, maar Satan en sy gevalle engele lei die mens van die wêreld op 'n dwaalspoor.

In neo-Platoniese terme word die stryd tussen goed en kwaad gesien as ' $\mathrm{n}$ afskaduwing van die groter stryd tussen God en Satan met sy demone. Die uiteinde is gewaarborg: God sal wen. Hierin lê troos en bemoediging vir die gelowige. Maar hierin lê ook die rede vir die vernietiging van die wêreld opgesluit. Satan en sy engele, wat met die sigbare wêreld geïdentifiseer kan word, sal vernietig word. Daarom sal die wêreld ook vernietig word. Die dualistiese denke is die aanleidende faktor vir die pessimistiese denke oor die toekoms van die wêreld.

God gaan spoedig ingryp, en die hele skepping gaan in die kosmiese konflik betrokke wees. Ná die kosmiese drama volg ' $n$ algemene opstanding en oordeel ${ }^{14}$. Die regverdige sal lewe terwyl die goddelose veroordeel word. Baie apokalipse beskou die opstanding van die dode as geestelik eerder as fisies, wat aansluit by die Hellenistiese antropologie wat die fisies-materiële as boos beskou.

Talle apokalipse is tussen die tweede eeu $\mathrm{vC}$ en die eerste eeu $\mathrm{nC}$ in Hebreeus, Aramees en Grieks geskryf, en is wyd gelees in Palestina en die Diaspora. Voorbeelde van apokaliptiese materiaal is ook tussen die Qoemraan- of Dooie Seerolle gevind.

Teen die tweede eeu nC begin die populariteit van apokaliptiese denke afneem, nadat die rabbi's moontlik rondom die ontmoeting te Jamnia (of Jawne) in ca. 90 nC Judaïsme restruktureer, met die val van Jerusalem. Sekere elemente in Hellenistiese Judaïsme word as volksvreemd afgemaak, en as onaanvaarbaar vir hervormde Judaïsme verklaar. Onder dié elemente word die dualistiese siening van die kosmos uitgesonder, saam met die pessimistiese siening van die wêreld met sy gepaardgaande ontwikkelde eskatologie, en die klem op lewe ná die dood, en loon en straf in 'n nuwe wêreld. Ook die leer van die onsterflikheid van die siel word as vreemde element uitgesuiwer. Hervormde Judaïsme plaas groot klem op die Tora, en elemente wat nie in die Tora voorkom nie, word uitgewan. Dié elemente word beskryf as Hellenistiese dogmas wat deur

${ }^{14}$ Vir Daniël is daar slegs ' $\mathrm{n}$ gedeeltelike opstanding, alhoewel dit nie duidelik is wat die motivering hiervoor is nie - Daniël 12:2. 
talle kultusse en godsdienste van die dag gedeel word ${ }^{15}$. Die Misjna en die Tosefta word die belangrikste geskrifte naas die Joodse Bybel.

Die gevolg hiervan was dat apokaliptiese literatuur nie meer geskryf of gebruik word nie, nòg in Palestina nòg in die Diaspora. Vir dié rede oorleef geen van die apokaliptiese werke in hul oorspronklike tale, Aramees of Hebreeus, nie. Die uitsondering is Daniël, wat deels in Aramees en deels in Hebreeus geskryf is ${ }^{16}$.

Nóú verbind aan die opkoms van Joodse apokaliptiek, die gepaardgaande begrip van die heelal en menslike bestemming, is die ontwikkeling van die literatuur van die wysheidsteologie. Die belangrikste werke is Kohelet (ca. 270-220 vC), die Wysheid van Jesus ben-Sirag (ca. 180 vC), en die Wysheid van Salomo (ca. 100-50 vC) ${ }^{17}$.

\section{CHRISTELIKE KERK EN APOKALIPTIEK}

Die Apokaliptiese geskrifte wat bewaar gebly het, is slegs ' $n$ fraksie van wat in die antieke wêreld gefunksioneer het. Dié boeke verteenwoordig die korpus wat deur die Christene hoog aangeslaan is. Dat die boeke enigsins oorgelewer is, al is dit dan in (hoofsaaklik) Griekse vertaling, is aan die Christelike kerk te danke. Christene het teen die einde van die eerste eeu nC die apokaliptiese element van die tussentestamentêre periode deeglik hul eie gemaak. Dat die Christene die Joodse apokaliptiese werke aanvaar het, is ook ' $n$ belangrike faktor in ortodokse Judaïsme se verwerping daarvan, wat veral ná $70 \mathrm{nC}$ alle bande met die Christelike kerk doelbewus verbreek (Russell 1964:32).

Die Christendom begin onder die sosiaal en finansieel agtergeblewe Jode. Dié groep, wie se lewensingesteldheid deur vervreemding, angs en wanhoop gekenmerk is, word bereik deur Jesus se apokaliptiese boodskap van die koninkryk wat reeds besig is om aan te breek. Jesus rig sy werk op plattelandse Joodse mense in die klein dorpies van Galilea. Sy volgelinge beskou Hom as die Messias, die een wat hulle van die huidige wêreld van swaarkry en verdrukking kom red en verlos ${ }^{18}$.

\footnotetext{
15 Die rabbi's was natuurlik reg, en dit bevestig dan ook die hipotese van dié artikel, dat apokaliptiek gebore is uit Joodse kontak met die Hellenisties-Romeinse wêreld.

${ }^{16}$ Geen aanvaarbare verklaring is nog aangebied vir die taalverdeling van die boek, wat nie met die vormkritiese verdeling ooreenstem nie: die verhale kom in Daniël 1-6 voor en die visioene in 7-12, terwyl Hebreeus in Daniël 1, 7-12 voorkom en Aramees in 2-6.

17 'n Wye korpus van navorsing oor Joodse wysheid het oor die jare ontstaan. Vir 'n kort oorsig, vergelyk Newsome (1992:84-85).

${ }^{18}$ Vergelyk vir een voorbeeld Marta se woorde op Jesus se vraag in Johannes 11:25 of sy in Hom glo: "Ja, Here, ek glo vas dat U die Christus is, die Seun van God, die Een wat na die wêreld toe moes kom" (my kursivering). Die naam "Jesus" is die Griekse weergawe van die Hebreeuse "Jah is redder", terwyl "Christus" die Griekse vertaling van die betekenis van die Hebreeuse "Messias" is.
} 
Die Christelike beweging begin as ' $\mathrm{n}$ apokaliptiese sekte binne Judaïsme (Tripolitis 2002:92). Verskeie soortgelyke sektes het waarskynlik in die eerste eeu onder Jode gefunksioneer, en veral Galilea was bekend as ' $n$ streek waar soortgelyke verwagtings hoogty gevier het $^{19}$.

In die tweede helfte van die eerste eeu $\mathrm{nC}$ word die Joodse komponent in die Christelike kerk al kleiner en gemarginaliseer. Die meerderheid Joodse Christene migreer uit die land. Ander assimileer met die heidense Christendom. ' $n$ Klein Joodse Christengemeenskap gaan bly in Pella, ' $n$ Griekse dorp aan die oostekant van die Jordaan. Hulle bly getrou aan die Tora en oorleef as die sekte van Ebioniete, genoem na die Hebreeuse woord vir "arm".

Ná 70 nC floreer en groei die Christendom onder die nie-Jode. As universele godsdiens is die deur oop vir mense van alle rasse en klasse. Binne veertig jaar nadat Jesus aan die kruis gesterf het, versprei die Christendom regdeur die bekende wêreld, hoofsaaklik danksy die suksesvolle sendingwerk van Paulus.

Die Christendom ontstaan binne die raamwerk van Hellenistiese Judaïsme. Dit aanvaar Joodse monoteïsme, die konsep van een, persoonlike God, asook ' $n$ streng morele kode afgelei van die etiese vereistes van die Tora, en die behoefte aan ' $n$ bekering, wat bestaan dat die rug op ander gode gedraai word. Apokaliptiek word ' $n$ integrale deel van Christelike denke, met ' $n$ imminente paroesie-verwagting as belangrikste element daarvan.

Christene se boodskap van hoop dat die mens van die bose wêreld verlos gaan word, aanvaarding van alle mense binne hul liefdesgemeenskap en sterk organisasie trek mense van die HellenistiesRomeinse era. Nes die misteriekultusse bevredig die Christelike boodskap die emosionele en geestelike behoeftes van ' $n$ groep mense. Teen die einde van die tweede eeu is die Christendom in al die belangrikste stede asook plattelandse distrikte gevestig.

\section{GNOSTISISME EN APOKALIPTIEK}

Gnosis is esoteriese kennis van die goddelike, die heelal en die mens, en van die mens se plek in die wêreld en bestemming. Dié kennis is geheim en slegs geopenbaar aan ingewydes. Die verband met die misteriegodsdienste is duidelik, waar sekere kennis ook slegs aan geïnisieerdes bekend is. In albei gevalle is die kennis die sleutel tot soteria, wat bestaan uit redding in en van dié wêreld.

\footnotetext{
${ }^{19}$ Handelinge 5:37 verwys na Judas die Galileër wat tydens die volkstelling in opstand teen die Romeine gekom het. Hy is in die opstand doodgemaak.
} 
Die verband met apokaliptiek bestaan hierin dat albei verskynsels vanuit dieselfde hoop leef. Die stelling kan gemaak word dat gnostisisme die reaksie van 'n deel van die Christelike kerk was op 'n teleurgestelde apokaliptiese verwagting ${ }^{20}$. Die historiese oorspronge van die gnostiese beweging gaan egter verder as Hellenistiese Judaïsme, en moet waarskynlik ook gesoek word in Hellenistiese filosofiese denke, die Christendom en Oosterse godsdienstige denke, by name Egiptiese, Siriese, Iranese en Indiese denke ${ }^{21}$.

Die Gnostikoi beskou hulself as uitverkore mense, 'n elite groep wat teenoor die oningeligte, materieel behepte massas staan.

Die vroegste getuienis van Christelike Gnostisisme kom in geskrifte van die tweede eeu nC voor. Sommige elemente, leerstellings en tendense van Christelike Gnostisisme kom ook voor in pre-Christelike en Judaïstiese geskrifte ${ }^{22}$. Gnostisisme was ' $n$ verskynsel wat groei uit die immer veranderende omstandighede van die dag en die voortgaande lyding en moeilikheid wat in individue ' $n$ lewensingesteldheid van vervreemding en ' $n$ gevoel van onveiligheid veroorsaak. Hieruit groei ' $n$ radikalisme wat tot die sosio-religieuse opstand van Gnostisisme lei. Gnostici verwerp die wêreld en voel vervreemd daarvan. Hulle verwerp ook die tradisionele sienings van die goddelike, asook die mens en sy plek in die heelal en bestemming. Hulle wil deur gnosis toegang tot die wêreld kry wat verby die huidige strek. Dié wêreld bied vryheid van die sondige materiële. Die verband met die heersende Hellenistiese kosmologie is duidelik ${ }^{23}$.

Gnostici verklaar hulself vry om hul eie individuele standaarde van gedrag en etiese waardestelsels te bepaal (Green 1977:169-180). Gnostiese sosiale gedrag was asketies of libertyns. Hierdie twee uiterstes vertoon dieselfde fundamentele ingesteldheid teenoor die wêreld, naamlik

\footnotetext{
${ }^{20}$ Die bespreking word weer eens besperk tot Christelike gnostiek. Die verskynsel kom oor talle grense voor, en bewys dat dit 'n produk van en reaksie op die tydsgees was.

21 Vir ' $n$ bespreking van historiese oorspronge, vergelyk Nock (1964:255-279, Rudolph (1987:252-257) en Cohn (1993:119-231).

22 Die Christene wat Gnostisisme in die tweede eeu beveg, verwys dikwels na Simon Magus as die oorsprong van die dwaalleer. Simon se verhaal word in Handelinge 8:924 vertel. Simon het wel 'n dualistiese siening van die wêreld gehandhaaf, maar hy was nie 'n gnostikus nie. Sy sentiment lê in Hellenistiese Judaïsme en hy is ' $n$ monoteïs.

${ }^{23}$ Die belangrikste figure binne Christelike gnostiek is Basilides (130-150 nC), Marcion (140-160 nC) en Valentinus (140-160 nC). Die datums verwys na die periode waarin hul geskrifte waarskynlik verskyn het.
} 
die verwerping en bevryding daarvan met die gepaardgaande breuk met konvensionele norme vir gedrag (Rudolph 1987:252-257) ${ }^{24}$.

Gnostisisme is nie ' $n$ eenvormige godsdiens nie, maar eerder ' $n$ houding oor die heelal en die individu wat in ' $n$ aantal groepe gemanifesteer word binne Judaïsme, die Christelike kerk en die heidendom gedurende die tweede en derde eeue. Die beweging vloei uit die sinkretisme tussen filosofiese spekulasie, astrologie, mitologie en Egiptiese, Persiese, Joods-Hellenistiese en Christelike idees. Dit is ' $n$ filosofies-religieuse samesmelting van talle strome.

Gnostisisme deel met apokaliptiek ' $n$ radikale pessimistiese lewensgevoel, asook 'n dualistiese siening van die wêreld (Haardt 1971 en Filoramo 1990). Daar is twee wêrelde: 'n suiwer geestelike, goddelike, onsigbare hoër wêreld van lig, wat ooreenkoms toon met Platoniese Idees, en 'n materiële wêreld van boosheid, duisternis en onafwendbare dood.

God woon in die geestelike wêreld. Hy is die Vader van alles, die uiteindelike oorsaak van alles en die onkenbare God. Sy leefwêreld is die pleroma, 'n sfeer gevul met hemelse wesens of aeone. Iewers in tyd het 'n goddelike aeon vanuit die sfeer van lig geval. Die oorsaak van die val was onkunde, 'n gebrek aan gnosis. Dié aeon skep die materiële wêreld en mensdom. Die materiële wêreld is 'n kopie van die hemelse, maar bestaan as antitese tot die goddelike wêreld van lig. Die skeppergod is die demiurg. In talle gnostiese stelsels is hy ook die god van die Ou Testament.

Die demiurg het eers die bose geeste geskep en daarna die kosmos. Die bose geeste of heersers is die sewe planetêre sfere en die twaalf sterretekens. Die demiurg en die bose geeste heers oor die wêreld en elke mens. Hul heerskappy staan bekend as heimarmene, universele lot of bestemming (Grant 1970:6-7) ${ }^{25}$. Die heerskappy is tiranniek, met die doel om die mensdom te verslaaf. Die materiële wêreld is essensieel boos.

Die mens wat deur gnosis verlig word, word bevry van hierdie wêreld en vind sy plek in die wêreld van lig met die ware God.

Wat nodig is om gnosis te vind, is dat die mens sy goddelike natuur verstaan. Dan vind die mens die vonk van God in homself, en word hy as't ware gedeïfiseer.

Volledige bevryding van die materiële kom in die oomblik van die dood van die liggaam. Dan keer die gees terug na sy ware huis, die sfeer van lig. Die terugkeer is lank en moeisaam, verby die planetêre sfere waaruit dit ontstaan het. Om die dooies op hul moeisame tog te help word

${ }^{24}$ Dieselfde lewensingesteldheid gee aanleiding tot monastisisme, in die derde eeu nC in Egipte (Latourette 1953:224).

${ }^{25}$ Pagels (1979) en Rudolph (1987) bied meer inligting. 
gebede vir die dode voorgeskryf, asook magiese spreuke en misterieuse tekens en simbole. Sommige gnostiese groepe voer ook doodseremonies uit om die deurgang van die siel te vergemaklik, soos om die lyk met olie en water te salf. Wanneer die siel suksesvol deur die planetêre sfere gegaan het, skei siel en gees. Die gees gaan in die lig van God op.

Gnostieke eskatologie sluit nie by die dood af nie, maar laat ook ruimte vir die einde van die wêreld. Die wêreld sal tot 'n einde kom as alle ligpartikels teruggekeer het na die pleroma, wat tot herstel daarvan sal lei as die volmaakte toestand. Die wêreld sal dan geen lig oorhê nie en ophou bestaan. Die einde van die wêreld is finaal.

Binne die gnostiese beweging ontstaan nooit ' $n$ organisasie met ' $n$ vasgestelde kanon, kerk, normatiewe teologie of geloofsreël nie. Vir hoofsaaklik dié rede oorleef dit nie die tyd nie, en teen die derde eeu verdwyn dit binne die Christelike tradisie.

\section{POST-MODERNE LEEFWêRELD}

'n Saak kan uitgemaak word dat daar raakvlakke tussen die HellenistiesRomeinse leefwêreld en die postmoderne leefwêreld van die 21ste eeu bestaan. Albei word gekenmerk deur vinnige veranderings wat daartoe lei dat mense onseker, angstig en vervreemd voel. Die laaste deel van die hipotese is dat beide die vinnig groeiende New Age-beweging, met sy velerlei vorme, en ook die neo-paganisme vanuit dié lewensingesteldheid verstaan moet word, nes die geval was met die ontstaan en groei van apokaliptiek en gnostisisme ${ }^{26}$. In alle gevalle is die bewegings sinkretisties van aard, en poog dit om hoop te bied op 'n wêreld wat beter is en verby die huidige strek ${ }^{27}$.

In albei gevalle word ou tradisies en waardes voortdurend ontwortel, verdwyn statiese klasse- en ander samelewingstrukture, word sekerhede van die verlede fundamenteel bevraagteken en betwyfel, en word die toekoms onseker. Die mens beleef sy wêreld as onseker, onveilig en bevreemdend. Sy lewensingesteldheid raak dié van wanhoop, angs en vervreemding.

Die mens smag na soteria, redding en bevryding van die laste van verganklikheid, swaarkry en mislukking van menslike lewe. Hulle vind dié heil in 'n nuwe stelsel wat daarin bestaan dat die bestaande wêreld as boos verwerp word, terwyl die weg aangewys word om na die goeie wêreld, van lig en geluk, terug te keer. In vandag se wêreld het verbeterde kommunikasiemedia die grense tussen lande en volke uitgewis. Die Inter-

\footnotetext{
${ }^{26}$ Vir ' $\mathrm{n}$ volledige bespreking hiervan, vergelyk Dodds (1970) asook Tripolitis (2002:148-149) se opmerkings.

27 Veral Patterson (1921:91) bespreek die ooreenkoms in sinkretisme tussen die stelsels in besonderhede.
} 
net het 'n oikoumene geskep, 'n enkele wêrelddorpie waar almal binne sekondes kan weet as ' $\mathrm{n}$ terreuraanval op die Amerikaanse kontinent plaasvind, en die volle verloop van die aanval in besonderhede volg.

Dié vooruitgang skep egter ook talle vrae by die individu, oor sy identiteit en doel, die betekenis van sy lewe en bestemming. Om in dié behoefte te voorsien, ontstaan nuwe kultusse rondom nuwe religieuse denke, soos die New Age-beweging en neo-paganisme. Alhoewel tye en omstandighede verander het, kan die eggo's van die HellenistiesRomeinse wêreld en die moontlike oplossing wat daar aangebied is, tot in die postmoderne dag gehoor word (Tripolitis 2002:149).

\section{SINTESE}

Die bogaande diskussie het gelui dat apokaliptiek en gnostisisme uit dieselfde leefwêreld kom, naamlik die Hellenisties-Romeinse wêreld en dat beide verskynsels bepaal word deur die lewensingesteldheid van ' $n$ sekere groep mense op dié leefwêreld.

Hierdie leefwêreld bestaan uit barbare-invalle, burgeroorloë, politieke onstabiliteit, godsdienstige ongelowigheid en sosiale verandering. Die lewensingesteldheid wat dit tot gevolg het, is wanhoop, angs en vervreemding. Mense voel vervreemd en onveilig in hul wêreld. Hulle soek na soteria, bevryding van en uit die stukkende ondermaanse wêreld.

Beide apokaliptiek en gnostisisme bied soteria aan, deurdat albei beloof om die weg tot ' $n$ beter wêreld te wees. Die verband tussen JoodsChristelike apokaliptiek en Christelike gnostisisme bestaan voorts daarin dat gnostisisme die antwoord probeer bied op 'n teleurgestelde apokalipties-eskatologiese verwagting.

Die laaste deel van die hipotese beklemtoon dat die postmoderne wêreld raakvlakke vertoon met die Hellenisties-Romeinse wêreld, en dat die fenomenale belangstelling in die alternatiewe religieuse denke van sinkretisme hieruit verklaar kan word.

\section{Literatuurverwysings}

Angus, S 1967. The religious quest of the Greco-Roman world. New York: Biblo and Tannen.

Cohn, N 19932. Cosmos, chaos \& the world to come. The ancient roots of apocalyptic faith. New Haven: Yale Nota Bene.

Davies, P R 1985. Daniel. Old Testament guides. Sheffield: JSOT Press.

Dodds, E R 1970. Pagan and Christian in an age of anxiety. New York: W W Norton.

Evans, C A \& Flint, P W 1997. Eschatology, Messianism, and the Dead Sea Scrolls. Studies in the Dead Sea Scrolls and related literature. Grand Rapids; William B Eerdmans.

Feldman, L H 1993. Jew and Gentile in the ancient world. Princeton: Princeton University Press. 
Filoramo, G 1990. A history of Gnosticism. Cambridge, Mass.: Blackwell.

Grant, F C 1953. Hellenistic religions: The age of syncretism. New York: Liberal Arts.

Grant, M 1982. From Alexander to Cleopatra: The Hellenistic world. New York: Charles Scribner \& Sons.

Grant, R M 1970. Augustus to Constantine: The thrust of the Christian movement into the Roman world. New York: Harper \& Row.

Green, H A 1977. Suggested Sociological themes in the study of gnosticism. Vigiliae Christianae 31, 169-180.

Haardt, R 1971. Gnosis: Character and testimony. Leiden: E J Brill.

Hanson, P 1975. The dawn of apocalyptic. The historical and sociological roots of Jewish apocalyptic eschatology. Philadelphia: Fortress.

Hengel, M 1974. Judaism and Hellenism: Studies in their encounter in Palestine during the early Hellenistic period. Philadelphia: Fortress.

Jonas, H 19632. The Gnostic religion. Boston: Beacon.

Koester, H 1982. Introduction to the New Testament. I: History, culture and religion of the Hellenistic age. Philadelphia: Fortress.

Latourette, K S 1953. A history of Christianity. Volume 1. Beginnings to 1500. New York: Harper \& Row.

Lucas, E C 2002. Daniel. AOTC. Leicester, Eng.: Apollos.

Martin, L H 1987. Hellenistic religions: An introduction. New York: Oxford University Press.

Nel, M 2000. 'n Teologies-hermeneutiese ondersoek na Daniël 1 en 2. PhDproefskrif, Universiteit van Pretoria.

Newsome, J D 1992. Romans, Greeks, Jews: Currents of culture and belief in the New Testament world. Philadelphia: Trinity.

Nilsson, M P 1946. The new conception of the universe in Late Greek paganism. Eranos 44, 20-27.

Nock, A D 1964. Early Gentile Christianity and its Hellenistic background. New York: Harper \& Row.

Nock, A G 1964. Gnosticism. Harvard Theological Review, 57, 255-279.

Pagels, E 1979. The gnostic gospels. New York: Random House.

Patterson, L 1921. Mithraism and Christianity: A study in comparative religion. Cambridge: Cambridge University Press.

Rudolph, K 1987. The nature and history of Gnosticism. San Francisco: Harper \& Row.

Russell, D S 1964. The method and message of Jewish Apocalyptic, 200 BC-AD100. OTL. Philadelphia: Westminster.

Smith, J Z 1990. Drudgery divine: On the comparison of early Christianity and the religions of late antiquity. Chicago: University of Chicago Press.

Tripolitis, A 2002. Religions of the Hellenistic-Roman age. Grand Rapids: William B Eerdmans.

Walbank, C B 1970. Alexander and the Hellenistic world. Toronto: A M Hakkert. 